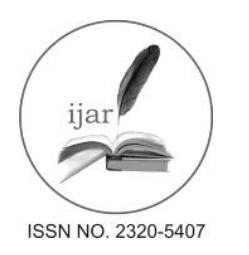

Journal homepage:http://www.journalijar.com
Journal DOI:10.21474/IJAR01

RESEARCH ARTICLE

\title{
INVITRO ANTIMICROBIAL ACTIVITIES OF LEAF EXTRACTS OF FIVE INDIGENOUS MEDICINAL TREE SPECIES FROM SEMI ARID REGIONS OF KATTAKADA, KERALA, INDIA.
}

INTERNATIONAL JOURNAL

OF ADVANCED RESEARCH

O"थ

NeethuS.Kumar*andNeethu Simon K.

Post Graduate Department and Research Centre of Botany, Mahatma Gandhi College, Thiruvananthapuram, Kerala, India.

\section{Manuscript Info}

Manuscript History:

Received: 14 March 2016

Final Accepted: 22 April 2016

Published Online: May 2016

Key words:

Antibacterial, Antifungal, Medicinal

Plants, Agar cup method

*Corresponding Author

NeethuS.Kumar.

\begin{abstract}
The present study reports the antimicrobial potential of 15 ethanol leaf extracts derived from commonly occurring five native medicinal tree species belonging to different families collected from the semi- arid regions of Kattakada, Kerala, India. The plants selected for the study were Annonasquamosa, Thespesiapopulnea, Murrayakoenigii, Glyricidiasepium and Moringaoleifera .Antimicrobial potential of these tree species were screened in vitro by the agar cup plate assay method against two bacterial and fungal isolates. Antibacterial activity was evaluated against two selected gram negative pathogens (Escherichia coli and Pseudomonas aeroginosa) whereas antifungal activity against two clinical fungal isolates (Candida albicans and Aspergillusniger). Among the varying concentration of leaf extracts, higher concentration exhibited maximum antimicrobial activity against the isolates. Antifungal activity were found to be low when compared to antibacterial activity. Highest antibacterial activity against P.aeriginosaand E.coli was exhibited by the leaf extracts of Moringaoleiferaand lowest by Murrayakoenigii . Whereas Thespesiapopulnea and Glyricidiasepium did not exhibit any antifungal activity. The results suggest that the leaves are a rich source of valuable primary and secondary metabolites which could be further exploited for the isolation and identification of active principle and for the evaluation of possible antimicrobial activity of other extracts from other parts of these tree species.
\end{abstract}

Copy Right, IJAR, 2016. All rights reserved.

\section{Introduction:-}

Since ancient times, people have been exploring the nature particularly plants in search of new drugs. This has resulted in the use of large number of medicinal plants with curative properties to treat various diseases (Verpoorte, 1998). Nearly $80 \%$ of the world's population relies on traditional medicines for primary health care, most of which involve the use of plant extracts (Sandhyaet al., 2006). In India, almost $95 \%$ of the prescriptions were plant based in the traditional systems of Unani, Ayurveda, Homeopathy and Siddha (Sathyavathiet al., 1987). The study of plants continues principally for the discovery of novel secondary metabolites.

Phytochemistry in the strict sense is the study of phytochemicals /phytonutrients which are non essential nutrients but still have been scientifically confirmed as being important to human health. These are chemicals derived from plants. They also exhibit a number of protective functions for human consumers.

For many years the adaptive significance of most plant secondary metabolites were unknown. These compounds were thought to be simply functionless end products of metabolism or metabolic wastes. Studies of these substances was pioneered by organic chemists of the nineteenth and early twentieth centuries who were interested in these substances merely because of their importance as medicinal drugs, poisons, flavoring agents etc. 
Plant based antimicrobials has enormous therapeutic potential as they can serve the purpose with lesser side effects that are often associated with synthetic antimicrobials (lwuet al., 1999).In recent years, secondary plant metabolites /phytochemicals, previously with unknown pharmacological activities, have been extensively investigated, as a source of medicinal agents (Krishnarajuet al., 2005). Thus it is anticipated that phytochemicals with adequate antibacterial efficiency will be used for the treatment of bacterial infections (Balandrinet al., 1985).The increasing failure of chemotherapeutics and antibiotic resistance exhibited by pathogenic microbial infectious agents has led to the screening of several medicinal plants for their potential antimicrobial activity (Colombo and Bosisio (1996), lwuet al., (1999). The presence of bioactive compounds indicates the medicinal value of plants. Antioxidants and antimicrobial properties of various extracts from many plants have recently been of great interest in both research and in food industry, because of their possible use as natural additives to replace synthetic antioxidants and antimicrobials with natural ones (Debaet al., 2008). Phytochemicals are antibiotic properties of plants and have been reported to possess antibacterial, antifungal and anti-inflammatory activities (Ajayiet al., 2011). Thus medicinal plants play an important role in the development of newer drugs because of their effectiveness, less side effects and relatively low cost when compared with synthetic drugs (Raj et al., 2001). Dubeyet al., in 2004 mentioned that the complete phytochemical investigations of medicinal plants in India should be carried out as the secondary metabolites are responsible for themedicinal activity of the plant.

Several classes of secondary metabolites have strong antimicrobial activity when tested in vitro and have been proposed to function as defenses against pathogens in the intact plants. Among these, sapponins a group of triterpenes are thought to disrupt fungal membranes by binding to sterols. Many species react to fungal or bacterial invasion by synthesizing lignin or callose. These polymers serve as barriers, walling of the pathogen from the rest of the plant and physically blocking its spread. Certain proline rich proteins of the wall become oxidatively cross linked after pathogen attack in $\mathrm{H}_{2} \mathrm{O}_{2}$ mediated reaction (Bradelyet al., 1992). This process strengthen the walls of the cells in the vicinity of the infection site, increasing their resistance to microbial digestion.

Another defensive response to infection is the formation of hydrolytic enzymes that attack the cell wall of the pathogen. An assortment of glucanases, chitinases and other hydrolases are influenced by fungal invasion. Perhaps the best studied response of plants to bacterial and fungal invasion is the synthesis of phytoalexins. Plant products have been part of phytomedicines since time immemorial. These can be derived from any part of the plant like bark, leaves, flowers, seeds etc (Cragg, 2001). Therefore a thorough knowledge about the chemical constituents of the plant is desirable as such information will be of great value for the synthesis of complex chemical substances. Such phytochemical screening of various plants is also reported by Ashok Kumar in 2010. In the present work, antibacterial and antifungal properties were carried out in the leaf extracts of five indigenous medicinal tree species such as Annonasquamosa, Thespesiapopulnea, Murrayakoenigii, Glyricidiasepiumand Moringaoleifera collected from Katakkada area in Kerala.

\section{Materials and methods:-}

\section{Collection and identification of plant materials:-}

Fresh plant/plant parts were collected randomly from the semi arid regions of Kattakada, Thiruvananthapuram, Kerala, India. The different parts of these plants used in Ayurveda and traditional systems of medicine are given in Table 1. Taxonomic identities of these plants were confirmed by Dr. Neethu S Kumar, at Post Graduate Department and Research centre of Botany, Mahatma Gandhi College, Kerala University. Fresh plant material was washed under running tap water, air dried, homogenized to fine powder and stored in air tight bottles.

\section{Preparation of plant extract for antimicrobial screening:-}

Ethanol extracts were prepared by mixing ten grams each of powdered leaf samples with $100 \mathrm{ml}$ of the solvent separately in a mechanical shaker at $100 \mathrm{rpm}$ for 48 hours at room temperature. Supernatant was collected and the solvent was evaporated to make the final volume one fourth of the original volume. For antimicrobial screeningthe concentrated, dried and powdered ethanol leaf extract was dissolved in $10 \%$ dimethyl sulfoxide (DMSO) and were stored at $4^{0} \mathrm{C}$ for further use.

\section{Test Organisms:-}

Antibacterial activity was evaluated against two selected gram negative pathogens such as Escherichia coli and Pseudomonas aeroginosawhereas antifungal against two clinical fungal isolates such as Candida albicansand Aspergillusniger ( as recommended by the National Committee for Clinical Laboratories Standards NCCLS), 
purchased from Biogenix Research Centre, Valiyavila, Thiruvananthapuram. In order to access the biological significance and ability of the plant part, the minimal inhibitory activity was determined by Agar cup plate assay method.

\section{Antibacterial activity:-}

Petri plates containing 20ml of Muller Hinton medium were seeded each with $24 \mathrm{hr}$ old culture of bacterial strains such as E.coliand P.aeroginosa.Wells of approximately $10 \mathrm{~mm}$ diameter were bored using a well cutter and $25 \mu 1,50$ $\mu \mathrm{l}$ and $100 \mu \mathrm{l}$ of the extracts were added to the wells from a stock concentration of $0.1 \mathrm{~g} / 1 \mathrm{ml}$. The plates were then incubated at $37^{\circ} \mathrm{C}$ for 24 hours. Antibacterial activity was assayed by measuring the diameter of the inhibition zone in millimeters formed around the wells. Gentamycin (standard antibacterial agent, concentration: $20 \mathrm{mg} / \mathrm{ml}$ ) was used as a positive control.

\section{Antifungal activity:-}

Antifungal activity was also determined by Agar cup method.Potato Dextrose agar plates were prepared and overnight grown isolates of fungi such as $C$. albicansand A. nigerwere swabbed. Wells of approximately $10 \mathrm{~mm}$ diameter were bored using a well cutter and extracts of $25 \mu \mathrm{l}, 50 \mu \mathrm{l}$ and $100 \mu \mathrm{l}$ concentrations were added and the zones of inhibition were measured after overnight incubation which were then compared with that of standard antibiotics.Clotrimazole was used as a positive control.

\section{Results and discussion:-}

Our approach involved the collection, identification, extraction and antimicrobial evaluation of the ethanol leaf extracts derived from commonly occurring native plants growing in the semi arid regions of Kattakada, Thiruvananthapuram, Kerala. In this study, 5 tree species belonging to 5 different families were collected randomly. Most of these plants were reported to treat a variety of diseases in traditional system of medicine. Local names (in Malayalam), family names and the respective plant parts of these tree species used in Ayurvedic or traditional system of medicine were reported in Table 1 . The powdered ethanol leaf extracts of these tree species have been screened for the potential antimicrobial activities against two clinical bacterial and fungal isolates.

Table 1:- Taxonomic name, Common name, Family name and uses of plant species.

\begin{tabular}{|c|c|c|c|c|}
\hline Taxonomic name & $\begin{array}{l}\text { Common name } \\
\text { in Malayalam }\end{array}$ & Family name & Plant part used & Uses \\
\hline Annonasquamosa & Seethapazham & Annonaceae & Roots,ripefruits,leaves,bark & $\begin{array}{l}\text { Used in the treatment of epilepsy, } \\
\text { dysentery, cardiac problems, fainting, } \\
\text { constipation etc. }\end{array}$ \\
\hline Thespesiapopulnea & Cheelanthi & Malvaceae & $\begin{array}{l}\text { Leaves, fruits } \quad \text {,bark, } \\
\text { flowers }\end{array}$ & $\begin{array}{l}\text { In ayurveda, fruits are used for } \\
\text { control of diabetes, barks possess } \\
\text { astringent, hepato protective and anti } \\
\text { oxidant activity. }\end{array}$ \\
\hline Murrayakoeniggi & Curry leaf tree & Rutaceae & Leaves, root & $\begin{array}{l}\text { Wound healing capacity, memory } \\
\text { improving effect, antioxidant } \\
\text { activity. }\end{array}$ \\
\hline Glyricidiasepium & Sheemakonna & Papilionaceae & Whole plant & $\begin{array}{l}\text { Wound dressing, treatment of } \\
\text { dysentery, anti bacterial and anti } \\
\text { fungal activity. Used as primary } \\
\text { health care. }\end{array}$ \\
\hline Moringaoleifera & Muringa & Moringaceae & Leaves, root & $\begin{array}{l}\text { Leaves and roots are used as } \\
\text { astringent and to relieve pain in gut. } \\
\text { Used against arthritis, cancer, gastro } \\
\text { vascular and heart diseases. }\end{array}$ \\
\hline
\end{tabular}

\section{Antibacterial activity:-}

Antibacterial activity of five tree species (leaf ethanol extract with DMSO) was assayed in vitro by agar cup method against two clinical gram negative isolates viz. E.coliand P.aeroginosa. Standard antibiotics were tested for their activity and their zones of inhibition were recorded. Table 2 shows the zone of inhibition produced by the extracts on Muller Hinton agar against the respective bacterial pathogens. 
Table 2: Anti bacterial activity against Escherichia.coli and Pseudomonasaeroginosa.

\begin{tabular}{|c|c|c|c|c|c|c|}
\hline \multirow{2}{*}{ Samples } & \multicolumn{4}{|c|}{ Zone of inhibition in mm againstE.coliand P.aeroginosa. } \\
\cline { 2 - 7 } & \multicolumn{3}{|c|}{ E.coli } & \multicolumn{3}{c|}{ P.aeroginosa } \\
\hline Plants & $25 \mu \mathrm{l}$ & $50 \mu \mathrm{l}$ & $100 \mu \mathrm{l}$ & $25 \mu \mathrm{l}$ & $50 \mu \mathrm{l}$ & $100 \mu \mathrm{l}$ \\
\hline Annonasquamosa & - & 11 & 17 & - & - & 15 \\
\hline Thespesiapopulnea & - & - & 15 & - & - & - \\
\hline Murrayakoenigii & - & - & - & - & - & 12 \\
\hline Glyricidiasepium & - & 11 & 14 & - & - & 15 \\
\hline Moringaoleifera & - & - & 18 & - & - & 16 \\
\hline Gentamycin & 20 & 20 & 20 & 20 & 20 & 20 \\
\hline
\end{tabular}

The sequence of antibacterial activity of leaf extracts of $A$. squamosa against E.coliexhibited no activity at $25 \mu$ l but produced a $11 \mathrm{~mm}$ and $17 \mathrm{~mm}$ zones of inhibition at 50 and $100 \mu$ concentrations respectively and also produced a $15 \mathrm{~mm}$ inhibition zone at $100 \mu \mathrm{l}$ concentration against P.aeroginosa (Table 2) (Plates 1 to 6).

Thespesiapopulnea andMoringaoleifera did not exhibit any inhibitory activity against E.coliin both 25 and $50 \mu 1$ concentrations but produced a 15 and $18 \mathrm{~mm}$ zones of inhibition at $100 \mu$ l concentrations respectively (Table 2) (Plate 1,2,3). P.aeroginosa was not at all inhibited byThespesiapopulneaat any concentrations whereas Moringaoleifera produced a $16 \mathrm{~mm}$ inhibition zone at $100 \mu \mathrm{l}$ concentration (Table 2) (Plate 6). SimilarlyMurrayakoenigii did not exhibit any inhibitory activity against E.coliat all the three concentrations but produced a $12 \mathrm{~mm}$ zone of inhibition at $100 \mu \mathrm{l}$ against P.aeroginosa (Table 2) (Plate 4,5,6) whileGlyricidiasepiumproduced a 11 and $17 \mathrm{~mm}$ zones of inhibition in 50 and $100 \mu \mathrm{l}$ concentrations against E.coli and a $15 \mathrm{~mm}$ inhibition zone at 100 $\mu$ l concentration respectively against P.aeroginosa(Table 2) (Plates 1 to 6).

Glyricidiasepium was found to be more active against E.coli. Highest antibacterial activity against P.aeriginosa and E.coli was shown by Moringaoleiferawhereas, Murrayakoenigii showed the lowest. Glyricidiasepiumand Annonasquamosa were also found to have the good antibacterial activity. In all the plant extracts, antibacterial activity was expressed at varying degrees with the difference in concentration. Higher concentration of leaf extract shows highest antimicrobial activity. The result obtained might be considered sufficient for further studies for isolation and identification of active principle and for the evaluation of possible antimicrobial activity of other extracts from other parts of the plant. In Moringaoleifera glycosides, phytosterols, oils, sapponins, phenols and flavanoids were present and it showed highest antibacterial property. It was supported byValsaraj et al (1997) who stated that many plant extracts are used against microbial infections due to the presence of secondary metabolites in them such as phenols, essential oils, terpenoids, alkaloids and flavanoids. Flavanoids were present in Annonasquamosawhich was earlier studied and reported that flavanoids of Annonasquamosaexpose strong antibacterial activity.

\section{Anti bacterial activity againstEscherichia Coli.}

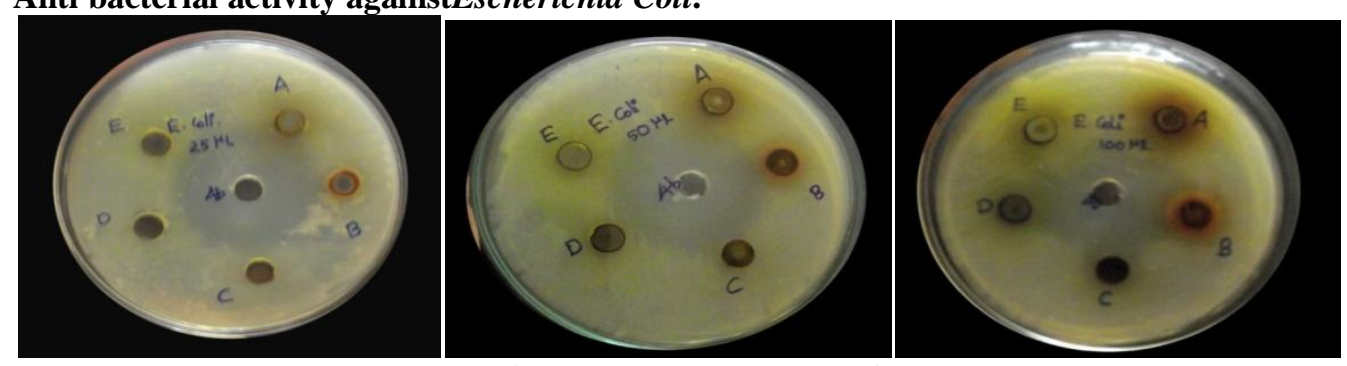
Plate: 1
Plate: 2
Plate : 3

Plates $1,2, \& 3$ showing the zone of inhibition produced by the ethanol leaf extracts at $25 \mu 1,50 \mu 1 \& 100 \mu l$ concentrations against E.coli. A-Annonasquamosa, B-Thespesiapopulnea, C-Murrayakoenigii, D-Glyricidiasepium, E-Moringaoleifera and Ab-Gentamycin. 
Anti bacterial activity againstPseudomonas aeroginosa.

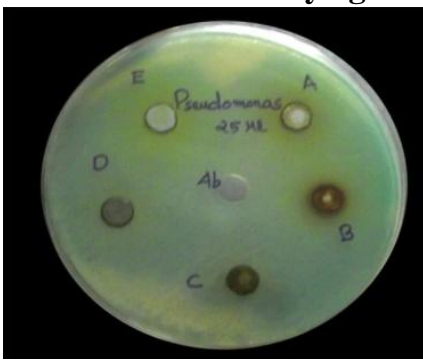

Plate : 4

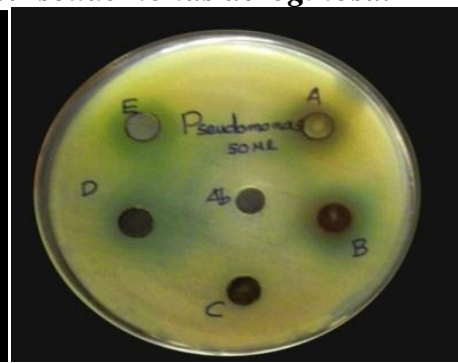

Plate : 5

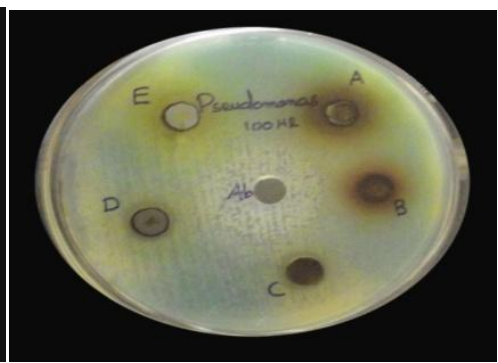

Plate : 6

Plates $4,5 \& 6$ showing the zone of inhibition produced by the ethanol leaf extracts at $25 \mu 1,50 \mu 1 \& 100 \mu 1$ concentrations against $P$. aeroginosa .A-Annonasquamosa, B-Thespesiapopulnea, C-Murrayakoenigii, DGlyricidiasepium, E-Moringaoleifera and Ab-Gentamycin

\section{Antifungal activity:-}

The antifungal activity of the leaf extracts ofAnnonasquamosa, Thespesiapopulnea, Murrayakoenigii, Glyricidiasepium, andMoringaoleifera were assayed invitro by agar cup method against two fungal species. The given table shows the microbial growth inhibition of ethanolic extracts of the screened plant species.

Table.3:Antifungal activity against Candida albicans and Aspergillusniger.

\begin{tabular}{|c|c|c|c|c|c|c|}
\hline \multirow{2}{*}{ Samples } & \multicolumn{5}{|c|}{ Zone of inhibition in mm against C.albicans and A.niger } \\
\cline { 2 - 7 } & \multicolumn{3}{|c|}{ C.albicans } & \multicolumn{3}{c|}{ A.niger } \\
\hline Plants & $25 \mu \mathrm{l}$ & $50 \mu \mathrm{l}$ & $100 \mu \mathrm{l}$ & $25 \mu \mathrm{l}$ & $50 \mu \mathrm{l}$ & $100 \mu \mathrm{l}$ \\
\hline Annonasquamosa & - & - & 11 & - & - & - \\
\hline Thespesiapopulnea & - & - & - & - & - & - \\
\hline Murrayakoenigii & - & - & 11 & - & - & 11 \\
\hline Glyricidiasepium & - & - & - & - & - & - \\
\hline Moringaoleifera & - & - & - & - & - & 14 \\
\hline Clotrimazole & 25 & 25 & 25 & 25 & 25 & 25 \\
\hline
\end{tabular}

The sequence of antifungal activity of leaf extracts of Annonasquamosa againstC. albicans was $11 \mathrm{~mm}$ at $100 \mu \mathrm{l}$ concentration whereas the activity was not found in both 25 and 50 $\mu$ l concentrations respectively(Table 3) (Plates $7,8,9)$. Annonasquamosa has no inhibitory activity against $A$. niger at all the three different concentrations (Plates $10,11,12)$.

Thespesiapopulnea andGlyricidiasepium did not exhibit any antifungal activity against both the fungal isolates at all the various concentrations (Table 3) (Plates 7 to 12). The leaf extracts of Murrayakoenigii had shown good activity at $100 \mu \mathrm{l}$ with a $11 \mathrm{~mm}$ zone of inhibition but did not exhibit any activity at both 25 and $50 \mu$ concentrations respectively against both fungal isolates (Table 3) (Plate 7 to 12). Moringaoleifera did not show any activity against $C$. albicans but exhibited a good activity against $A$. niger with an inhibition zone of $14 \mathrm{~mm}$ at $100 \mu l$ leaf extract concentration (Table 3) (Plate 7 to12). Murrayakoenigii and Moringaoleifera exhibited good inhibitory activity against $A$. niger. The reason for different sensitivity could be due to the difference in the phytochemical constituents present in the leaves of these plants.

\section{Antifungal activity against Candida albicans.}

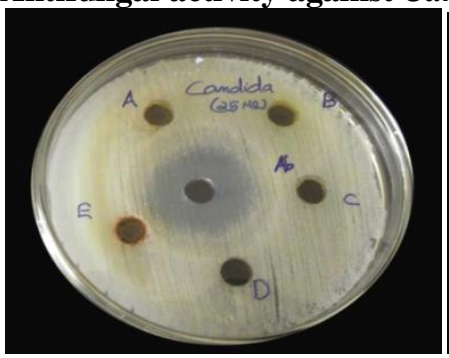

Plate : 7

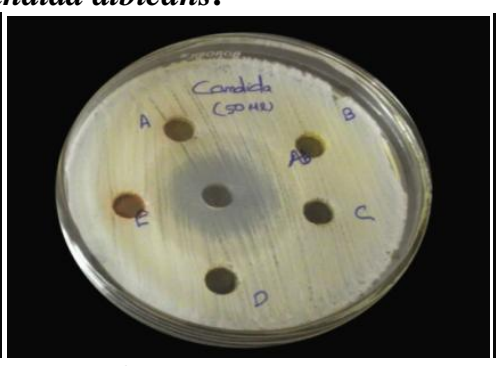

Plate : 8

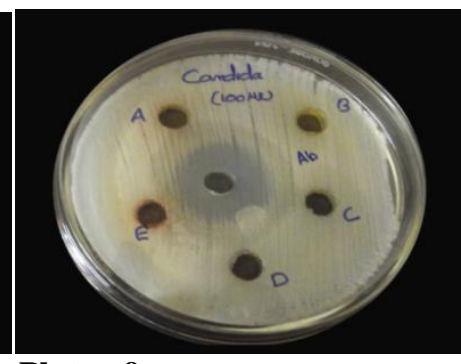

Plate : 9 
Plates 7,8 and 9 showing the zone of inhibition produced by the ethanol leaf extracts at $25 \mu 1,50 \mu l \& 100 \mu l$ concentrations against $C$. albicans A-Annonasquamosa, B-Thespesiapopulnea, C-Murrayakoenigii, DGlyricidiasepium, E-Moringaoleifera and Ab- Clotrimazole.

Antifungal activity against Aspergillusniger.

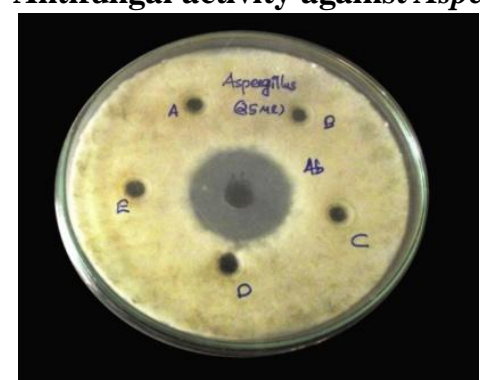

Plate :10

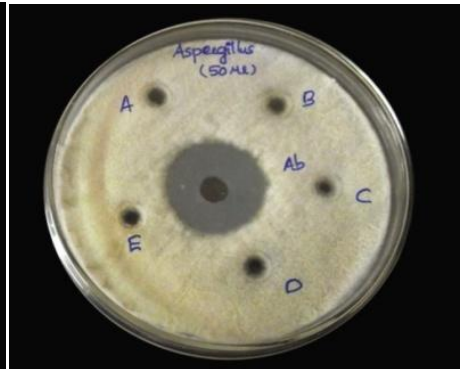

Plate :11

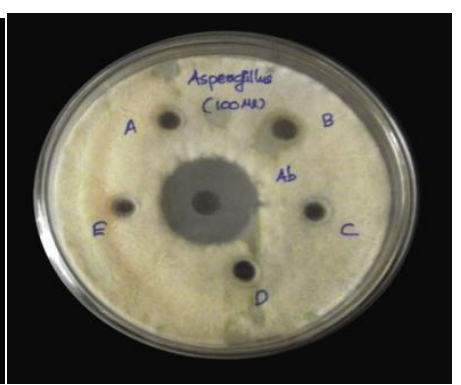

Plate : 12

Plates 10,11 and 12 showing the zone of inhibition produced by the ethanol leaf extracts at $25 \mu 1,50 \mu 1 \& 100 \mu l$ concentrations against A. nigerA-Annonasquamosa, B-Thespesiapopulnea, C-Murrayakoenigii, D-Glyricidiasepium, E-Moringaoleifera and Ab- Clotrimazole.

\section{Conclusion:-}

In the present work all the tree species studied had shown better antibacterial activity than antifungal activity. In literature it has been indicated that the antibacterial activity is due to presence of different chemical agents in the extract including essential oils, flavanoids, terpenoids and other compounds of phenolic nature or free hydroxyl group which are classified as active antimicrobial compounds. These findings can form the basis of further studies to isolate active phytocemicals, elucidate them against wider range of bacterial strains with the goal to find new therapeutic principles.

The present study reveals that the leaf extracts of the above said plants were active againstE.coli and P.aeroginosa than the two fungal isolates studied. Antifungal activity were found to be negligible when compared to antibacterial activity. The results of the study supports to a certain degree, the usage of traditional medicinal plants in human and animal disease therapy and reinforce the concept that ethno botanical approach to screening plants as potential sources of bioactive substances is successful. Plants showing significant activity may be due to the presence of alkaloids, flavanoids, tannins and polyphenols . Among these extracts Moringaoleifera was the most active against both bacteria and fungi. The ethanol extract generally exhibits a high degree of antibacterial activity which seems to confirm the traditional therapeutic claims of these plants. The results suggest the presence of either good antibacterial potency or high concentration of an active principle in the extracts studied. Thus antibacterial activity would support the folk therapy of infections whose symptoms might involve bacteria.

\section{Acknowledgment:-}

The authors are thankful to the Director, Biogenix Research Centre, Valiyavila, Thiruvananthapuram for providing facilities for the completion of this work.

\section{References:-}

1. Verpoorte R. 1998. Chemodiversity and the biological role of Secondary metabolites, some thoughts for selecting plant material for drug development. ProcPhytochemSoc, Europe, Kluwer Publishers, 43:11-24.

2. Sandhya B, Thomas S, Isbael R. 2006. Complementary and alternative medicines, 3:110-114.

3. Sathyavathi G.V, Guptha A.K, Tandon.n,. 1987. Medicinal plants of India, Indian Council of Medical Research, NewDelhi, India.

4. Iwu M.W, Duncan A.R, Okunjio C.O. 1999. New antimicrobials of plant origin. Alexandria, VA:ASHS Press;pp:457-462.

5. Krishnaraju A.V, Rao T.V, Sundararaju D. 2005. Assesment of bioactivity of Indian medicinal plants using Brine Shrimp lethality assay. IInt J ApplSci Eng 2:125-134.

6. Balandrin M.F, Kjoecke A.J and Wurtele E. 1985. Natural plant chemicals source of industrial and medicinal plants. Science 228:1154-1160. 
7. Colombo M.L and Bosisio E. 1996. Pharmacological activities of Chelidoniummajus. Pharmacol Res33:127134.

8. Deba F, Xuan M, Yasuda M. 2008. Food control, 19:346-352.

9. Ajai I.A, Ajibade O, Oderinde R.A. 2001. Priliminary phytochemical analysis of some plant seeds. Res J Chem Sci;1(3), 58-62.

10. Raj B.A, Murugamani V, Madhuri B. 2011. Preliminary phytochemical investigation of Givotiamoluccana Stem. Int J Res Pharm Biomed Sci 2011, 2(3):1307-1313.

11. Dubey N.K. 2004. Global promotion of herbal medicine. Curr Sci;86:31-41.

12. Bradley D.J, Kjellborn P and Lamb C.J. 1992. A novel rapid defense response. Cell.70:21-30.

13. Cragg G.M and David J.N. 2004. Natural product drug discovery in the next millennium. J Pharm Biol;39:8-17.

14. Ashok Kumar P, Rajkumar and Kanimozhi M. 2010. Phytochemical screening and antimicrobial activity from five Indian medicinal plants against human pathogens. J Sci Res;5(3):157-162.

15. Valsaraj R, Pushpangathan P, Smitt U.W. 1997. Antimicrobial screening of selected medicinal plants from India. J Ethnopharmacol, 58:75-83. 